\title{
Building Trust: Reflections of School Principals Working With Students, Parents, and Teachers in an Intensive Language Training Center in Beijing
}

\author{
Wei Zhang \\ Western Michigan University \\ Tetyana Koshmanova \\ Western Michigan University
}

This study explores the experiences of school principals in building a trust-based relationship in promoting school effectiveness and improvement in a YBR private language training center in Beijing. A semistructural interview with thirty-one Chinese participants, including school principals $(N=1)$, teachers $(N=10)$, students $(N=10)$, and parents $(N=10)$, was employed through a qualitative descriptive and longitudinal research design. Findings showed that YBR school faces three major challenges: testing score results first but trust second; saving costs but neglecting the importance of promise and expectation; worrying about student dropout rate. However, this study found that school maintains trust through major themes: passing exams with the excellent testing score; communicating with parents and teachers; increasing teachers' engagement with high wage if high-qualified. Findings additionally showed three strategies of word of mouth, best-service, and market promotion for school principals to improve school enrollment rate, social reputation, and student achievement. Further studies on becoming the antiracist leader for leading dual-language programs through a qualitative comparative study between the United States and China were recommended.

Keywords: trust, China, leadership, dual-language program, social justice, school principal

\section{INTRODUCTION}

With the ongoing improvement of the Chinese economy, family per capita, educational policy, and globalization, school principals, parents, students, and teachers have changed their educational perspectives. Also, the Chinese Ministry of Education in 2013 announced the educational laws to advocate suzhi education in Chinese, translated as quality education in English to cultivate all-round education. The China Ministry of Education promulgated China's Education Modernization 2035 to rejuvenate the country through science and technology in February of 2019 (Zhu, 2019). The new Chinese educational policy has been driven by three factors: the UN 2030 agenda, China's national strategy, and Chinese education reform. The education modernization 2035 emphasizes ethics in education, lifelong learning, integrated development, personalized teaching, well-round development, and people-orientation (MOE, 2019; Zhu, 2019). The education modernization toward 2035 requires China's education informatization 2.0 action plan, which means to use the national educational strategies "internet+" (Internet +Education), big data, and artificial intelligence to enter into the informatization 2.0 era (Yan \& Yang, 2020). The China 
modernization 2035 will achieve through the development of "Made in China 2025" and "Healthy China 2030" toward 2035 through the educational philosophy of uniting the hearts of the people, developing manpower, nurturing talents, and fostering all-round moral, intellectual, physical and aesthetic grounding with a hardworking spirit (MOE, 2019; Zhu, 2019). China emphasizes that Chinese education needs to be driven by high technology to cultivate students' comprehensive education and improve critical thinking, independent problem solving, and creativity. With a mindset of students with a spirit of service and contribution, school principals generate quality education in promoting students to become a top student (Baktir \& Watson, 2020; Zhang \& Koshmanova, 2020).

In Chinese social-cultural and philosophical perspectives, top students symbolize that they have the chance to enroll in the top national universities, even the world's prestigious schools in their college education. If the high schools could have a chance to cultivate more high school students to enter the top universities, the high schools would be indeed welcome by the parents, students, teachers, and school principals. However, not all students can receive their studies in the top public schools in mainland China due to many challenges, such as the Hukou system, which means only the residents with local hukou are eligible to participate in the national college examination and also have chance to enter the top high schools. Students who enter the top high schools would receive a college offer from top universities in mainland China mostly (Festenstein, 2020; Kwak, Tomescu-Dubrow, Slomczynski, \& Dubrow, 2020; Zhang \& Koshmanova, 2020).

Those migrated students without local hukou could not have the opportunity to enter the top public high schools, which assumed that they have no chance to enter the top national university. Only those from wealthy families may have chances to enter the top schools; however, not all students have the chances due to the hukou policy's restriction, the pressure of the national college entrance examination, and globalization impacts. Consequently, with the social needs, China has a mix of pre-collegiate schooling opportunities with the guidance, rules, and regulation to the three-tiered system: public-state supported schools, publiccommunity run schools (minban), and variations of private schools. The word "minban" school means the non-state education and run by the citizen, presented in Chinese spelling (Dong \& Li, 2019). Since the educational reform in the 1980s, the growing numbers of private schools (minban) have been increasing (Lyu, Li, \& Xie, 2019). The Law of Privately-Run Education Promotion (or Minban, non-state education, people-run schools) defined the rights and duties to give equal status to the private schools (Ding, 2004). Thus, non-state education institutions have increased rapidly in number and have become an integral part of China's educational system for providing an opportunity for parents to choose schools for their children (Huang, Wang, \& Li, 2016).

The government runs the public school, but the private or minban schools run by the citizens, which operates in relevant state laws and regulations. The community or government funds the public school, but the private schools are self-supporting, utilizing various funding mechanisms such as tuition, overseas Chinese support, and enterprise donations. Since the minban private schools run independently, the schools could revise the state curriculum and create their training modules. Thus, the private schools need to raise funds through their efforts and competitively hire teachers to provide quality education in the competitive school market (Dooley \& Creber, 2020; Janvier, Farlow, Barrington, Bourque, Brazg, \& Wilfond, 2020; Zhang \& koshmanova, 2020).

Since it is a private language training center, parents and students have many choices, only in Beijing, over thousands of training centers, thus causing many challenges for centers to maintain and increase the student enrollment rate for school effectiveness and social reputation. Due to the private school or center nature, the school founder often serves as a principal, teacher, and school leader. The private training centers could increase the students' enrollment rate and recruit good teachers only if the school principal could provide quality education and make the parents and students satisfied with their learning expectations. The school could recruit professional teachers only if the school could offer a high salary, thus causing the school to hire many part-time teachers instead of full-time ones. This viewing causes distrust among students, teachers, parents, and school principals because the language training center is afraid of losing students. Therefore, the school principal tends to pay much attention to the expectations from parents and students. Only if the school could help the students pass the exam with a high score could increase the 
school reputation, enrollment rate, and school improvement, creating a trust-based interpersonal relationship with all stakeholders (Zhang \& Koshamanova, 2020).

Only if the school principal could guide the teachers to satisfy the students' and parents' expectations could increase the school development. The school principals hold a distrustful attitude in leading the school improvement. The school principal's primary goal is to maintain its reputation, increase enrollment rate, and build a relationship with parents, students, and teachers in promoting school improvement. School principals are afraid of the teachers who could not guide them to achieve their learning goals because most of them are part-time. Maintaining a trust-supportive relationship with students and parents depends on how principals could work with teachers to engage their expectations. In reality, students and parents still distrust the school principals, teachers, and school because they still have many chances. For example, three of the students did not accept the school principals' and teachers' advices that caused them to face many troubles in learning; but two or three years later after training, they complained to the training centers. Therefore, creating trust-based teaching and learning school climate is essential for school improvement, student recognition and overcoming the challenges in the competitive school market in Beijing.

Therefore, the private language training center principals could build a trust-based relationship with stakeholders only if the centers could fit the students' and parents' expectations in learning. However, advocating a trust interpersonal learning environment is a key for school principals to win respect from parents, students, and teachers. Specifically, this study explores the school principals' experiences of building a trust-based relationship in promoting school effectiveness and improvement based on the authors' teaching and administrating experiences in a YBR private language training center in Beijing (YBR school) from 2012 to 2019. The YBR school registered in 2012 as a "minban " school in Beijing and has offered an intensive language training program to those students who prepared their language proficiency for a standardized test. The citizen runs the YBR school through promotion, cooperation, and program training quality for sustainable growth. Therefore, this study explores the importance of trust and creating a trustbased learning environment among the school stakeholders in leading school improvement. The three research questions are as follows guided in this study.

1. What are the principal's challenges in building trust crisis among students, teachers, and parents in YBR school?

2. How could principals establish and maintain a relationship of trust among students, teachers, and parents in YBR school?

3. How does the school principal promote trust-based leadership to improve student enrollment rate, market share, school reputation, and develop students' critical, independent thinking ability in YBR school?

\section{LITERATURE REVIEW}

Trust facilitates the development of productive social relationships for school improvement and teacher collaboration, parent involvement, and student engagement in learning in the high-power distance school context (Li, Hallinger, \& Walker, 2016). Trust between school principals and teachers could cooperate to make school successful and also makes the parents involved in the school activity (Cosner, 2009) and encourage the student to develop their learning outcomes (Crane, 2020; Weinstein, Raczynski, \& Pena, 2020; Zhang \& Koshmanova, 2020). Creating a trust learning environment could promote the educational core values of benevolence, honesty, loyalty, and openness to both achieve school targets and school learning outcomes (Weinstein, Raczynski, \& Pena, 2020). If the school principals could create a trusted learning environment, the school stakeholders not only exchange their thoughts to achieve the school outcomes (Crane, 2020) but also build a strong friendship in leading school improvement and makes all school members feel secure (Groote \& Bertschi-Michel, 2020), and increase school social reputation and enrollment rate (Zhang \& Koshmanova, 2020). Therefore, the following literature review will cover the following themes: why trust is essential in YBR school; what benefits of creating trust between parents and school principal; the trust between teachers and principals for the quality of teaching, teachers sense of 
responsibility, and teaching evaluation; and trust between students and principals for student learning outcomes.

\section{Why Trust Is Important in YBR School}

In the power distance and guanxi social-cultural school context in Beijing, the YBR school needs to build a social connection for school improvement. This viewing indicates that Chinese people deeply trap in an intricated web of guanxi, the Chinese term for social connections. The traditional concepts of guanxi describe the fundamental dynamic in personalized networks of influences. The concept of guanxi originates from Confucianism for Chinese people to enlarge their social network for life and study (Lin \& Huang, 2017). The Chinese people develop and sustain relationships (guanxi) within school stakeholders for school improvement depending on the degree of trust for their decision-making (Lin \& Huang, 2017). Chinese parents choose schools for their children through a variety of channels and means, including money (school fees, sponsorship fees), power, guanxi, and academic achievement (test scores, honorary awards, friends' recommendation, and trust (Dong \& Li, 2019). Therefore, creating a trusting relationship among school principals, students, parents, and teachers is essential in school improvement for several reasons.

First, high trust among school stakeholders indeed affects students' test scores. Bryk \& Schneider (2002) said that schools with a high trust are three times as likely to increase students' test scores (p. 111), and also schools with high relational trust improved reading scores by $8 \%$ and math scores by $20 \%$ over five years (p. 40). Second, high trust between school principals and teachers could help the students achieve their learning goals and create a healthy school learning environment. Handford and Leithwood (2013) said that "the sense of trust, confidence, enthusiasm, and friendliness among teachers" is one of the seven features of a "healthy" school (p. 10). Third, high trust among school stakeholders enables school improvement, such as setting high academic targets, developing effective instructional strategies, and creating a trust supportive learning community (Handford \& Leithwood, 2013). Therefore, creating a high trust learning climate is a key for YBR school to provide a high quality of education to students and improve school social image.

\section{What Benefits of Creating Trust Between Parents and School Principals}

Establishing a trusting relationship between the principal and the parents can benefit the school improvement. First, parents' trust in the school's principal can help parents actively participate in school activities and express their expectations. In this way of active communication, the principal can work with parents to cooperate and provide more efficient education to their kids. Tschannen-Moran (2009) said that parents' trust is vital in building and maintaining trust between family-school relationship, parent-school confidence, parent-principal trust, and parent collaboration. With a trust-based relationship between parents and school principals, parents tend to involve the school activities for student learning. Second, parents can actively accept the principal's constructive, professional suggestions and actively cooperate with the school's guidelines. This viewing could help school principals and teachers to provide sufficient support to the students in learning. Erden and Erden (2009) stated that parent-principal trust motivates parents to cooperate with schools for their children's' learning expectations. Third, due to parents' concerns about the school Trust, trust in the principal can indirectly carry out positive publicity to the school, thereby increasing the school's popularity and the school's student enrollment rate. Parents' trust will consciously or unconsciously carry out positive advertising about the school in their life and social network for school promotion. Since China relies on Guanxi to build social life network, parents' promotion is influential for school development. Therefore, the principal establishes a productive trust-based relationship with families to strengthen student learning outcomes and school improvement (Tan, Gao, \& Shi, 2020).

\section{Trust Between Teachers and Principals for the Quality of Teaching, Teachers' Sense of Responsibility, and Teaching Evaluation}

First, the trust relationship between a principal and a teacher can help teachers find a sense of belonging to devote themselves to education more responsibly, thereby helping students improve their grades (Skaalvik \& Skaalvik, 2011). Tschannen-Moran (2009) said that trust is considered a feature of an 
individual and a collective feature of teaching staff, referred to as faculty trust. Trust between teachers and school principals maintains the school's core values such as, benevolence, reliability, competence, honesty, and openness. Van Maele and Van Houtte (2012) also stated that teacher trust plays four dimensions in students, colleagues, parents, and principals. Louis and Murphy (2017) further supported that principals' trust in teachers' professional competence motivates teachers to support students' success and vice versa.

Second, principals who promote a trusting and collaborative climate could work with teachers to provide quality education and help students learn outcomes effectively. Trust between principals and teachers lies at the heart of school improvement and also is a source of self-efficacy, collaboration, commitment, and building a strong sense of belongs with a responsibility to school members (Ghamrawi, 2011). While trusting among members, the principals could motivate teachers to do more than they initially expected (Handford \& Leithwood, 2013) because they feel trust, admiration, and respect. Third, with trust, teachers could pay attention to their teaching, and principals could also evaluate their teaching quality for student learning outcomes. One of the Chinese proverbs said: if the lips are lost, the teeth will be cold, which refers to the school stakeholders have to work together on school improvement.

\section{Trust Between Students and Principals for Improving Student Learning Outcome}

With a positive, trusting relationship with students, school principals could prevent misunderstanding and work with teachers to promote classroom and school-wide improvements such as creating opportunities for professional dialogue and examination of student work (Gregory, Hafen, Ruzek, Mikami, Allen, \& Pianta, 2016; Murphy et al., 2006). With a trust-based learning environment, school principals can effectively foster trust and help students learn from the mistakes, enhancing teacher capacity and improving student learning, such as critical and independent learning ability (Johnston \& Shipway, 2020). RinconGallardo and Fullan (2016) supported that trusting between principal and student is fundamental for the openness to learning in the high-stake school context. Fundamental as high trust is for effective collaboration, and a strong relationship of trust goes hand with internal accountability. Developing trust and internal accountability takes time and building a relationship of trust is the best way to accelerate improvement in the long run for student learning achievement. Therefore, trust maintains consistency between values, goals, and activities which enhance the student learning outcomes, and school principals could create a school climate conducive to increased collaboration, which in turn promotes the quality of teaching practices and student learning in the classroom (Alazmi \& Ai-Mahdy, 2020; Coban, Ozdemir, \& Bellibas, 2020; Tschannen-Moran, 2004; Thornton, 2021).

Therefore, trust among teachers, students, parents, and school principals in YBR school is significantly related to students' achievement. Trust in school principals is also a significant influence on school improvement (Handford \& Leithwood, 2013; Tan, Gao, \& Shi, 2020). With trust-based leadership, school principals could guide all school stakeholders to overcome rejection, failure, loss, and embarrassment for leading school improvement (Ghamrawi, 2011) and highly satisfied with the students' and parents' expectations in learning. Thus, school principals could improve the school's social reputation, enrollment rate, and student learning achievement and potentially increase school market share.

\section{METHODOLOGY}

\section{Research Design}

The qualitative descriptive inquiry was employed to analyze and understand the school principals, teachers, parents, and students' experiences and explore their perceptions, opinions, beliefs, and values, such as trust in school (Creswell, 2007). Since the YBR school runs by the citizen through increasing the enrollment rate, providing a quality of the program, and improving its images in the competitive school sectors, the YBR school principals ensure to provide a quality of training which granted the students, parents, and teachers who are satisfied and also engage their expectation. In general, the minban schools, such as YBR school, a small private school, need to enlarge their service only if they could provide a high-quality educational program. However, many parents and students tend to choose reputable and large schools for their studies; if the students and parents do not know the school or the school principals, the small private 
school might have difficulty recruiting more new students. Only if the private school, such as YBR school, could help the students achieve their learning goals and make the parents feel satisfied with their expectations, the school may have a chance to recruit more new students from the word of mouth of students and parents.

Since China is a guanxi social network, the school principals need to create good guanxi with students, parents, teachers, and partners, which are necessary. Specifically, the YBR school maintains and sustain the school growth and provide a quality of service to helping students to reach their learning goal. The YBR schools need to understand how the students and parents think and expect while selecting a school for study; and what the school needs to implement for school sustainability. The study aims to collect the principal, teacher, parent, and students' opinions, expectations, and beliefs through observation, interviews, fieldnote, and memos to discover what elements are essential for students and parents to essential school for their study. This study aims to understand the experiences, opinions, and beliefs of principals, teachers, parents, and students on how the school principals could implement the school program and provide a high-quality program for students in achieving their learning goal (Denzin \& Lincoln, 2005; Lincoln \& Cuba, 1985). Although this study is based on the researchers' living experiences with participants in the school contexts, the author maintains the validity through random selection, audit, and member check for in-depth analysis and understanding in the fields. Therefore, this descriptive analysis approach uses to analyze the participants' experiences, beliefs, and opinions through coding, categorizing, and synthesizing (Miller, Chang, \& Farmer, 2018; Saldana, 2018) in this study.

\section{Positionality and Participants}

The interview study explores the importance of trust and creating a trust-based learning environment among school stakeholders to lead school improvement. Specifically, this study emphasizes the importance of trust and expects to answer the following three research questions. What are the principal's challenges in building trust crises among students, teachers, and parents in YBR school? How could principals establish and maintain a relationship of trust among students, teachers, and parents in YBR school? How does the school principal promote trust-based leadership to improve student enrollment rate, market share, school reputation and develop students' critical, independent thinking ability in YBR school? The research's positionality significantly impacts informants' access and understanding of experiences, beliefs, and perceptions through data analysis. One of the authors received higher education in both western and eastern cultural contexts and worked in China's private language centers for over ten years. He has worked in the center and collaborated with several schools under the centers as educational projects. The author understands the educational reality and observed the language training environment, teacher job satisfaction, parent expectations, and student learning pressures in China's high power distance learning environment (Ro, 2019). The study maintains ethical reports, beneficence, and justice (Denzin \& Lincoln, 1994). The study has used the participants' anonymity to understand the school principals, teachers, students, and parents' lived experiences in China's Confucian context. Thirty-one participants were employed in this study and the participants of school principal $(\mathrm{N}=1)$, teachers $(\mathrm{N}=10)$ are shown in the table 1 below and parents $(\mathrm{N}=10)$ and students $(\mathrm{N}=10)$ are shown in the table 2 below.

\section{TABLE 1 \\ OVERVIEW OF THE PARTICIPANTS OF SCHOOL PRINCIPAL AND TEACHERS AT YBR* SCHOOL IN BEIJING}

\begin{tabular}{llllll}
\hline Coding & Position & Gender & Age & $\begin{array}{l}\text { Years of Working } \\
\text { Experience }\end{array}$ & $\begin{array}{l}\text { Graduate } \\
\text { Degrees }\end{array}$ \\
\hline Principal 1 & School Principal & $\mathrm{M}$ & 45 & 15 & MBA \\
Teacher 1 & English Teacher & $\mathrm{F}$ & 35 & 5 & MA \\
Teacher 2 & English Teacher* & $\mathrm{F}$ & 31 & 3 & $\mathrm{BA}$ \\
Teacher 3 & English Teacher & $\mathrm{M}$ & 52 & 20 & $\mathrm{BA}$ \\
Teacher 4 & English TOEFL Teacher* & $\mathrm{M}$ & 35 & 6 & MA \\
\hline
\end{tabular}




\begin{tabular}{llllll}
\hline Teacher 5 & Science Math Teacher & F & 36 & 4 & BS \\
Teacher 6 & SAT Math Teacher* & F & 28 & 3 & BS \\
Teacher 7 & SAT Math Teacher* & M & 32 & 5 & BS \\
Teacher 8 & English Teacher* & F & 56 & 26 & BA \\
Teacher 9 & $\begin{array}{l}\text { Chinese Language } \\
\text { Literature Teacher* }\end{array}$ & M & 60 & 35 & BA \\
Teacher 10 & English Teacher* & F & 28 & 2 & MA \\
\hline
\end{tabular}

*Pseudonyms \& part-time teachers

Table 1 shows that there are seven part-time teachers, which might cause the school face challenges because sometimes the school might have the chances to recruit the part-time teachers to teach the students in YBR school. In general, the part-time teachers are high qualified in the field of their teaching because they travel around in the various centers in their teaching in Beijing. Therefore, the centers could have the chance to recruit the part-time teachers to teach teachers only if the centers could arrange in advance. The following table 2 shows the participants and students in the school below.

TABLE 2

OVERVIEW OF PARTICIPANTS OF PARENTS AND STUDENTS AT YBR SCHOOL IN BEIJING

\begin{tabular}{llll}
\hline Coding & Position & Gender & Social Status \\
\hline Parent 1 & High School Parent & M & Medical Doctor \\
Parent 2 & High School Parent & M & Nurse \\
Parent 3 & High School Parent & M & Company Worker \\
Parent 4 & High School Parent & M & Company Sectary \\
Parent 5 & High School Parent & F & Medical Doctor \\
Parent 6 & Middle School Parent & F & Company General Manager \\
Parent 7 & Middle School Parent & F & Worker \\
Parent 8 & Middle School Parent & F & General Manager \\
Parent 9 & College Parent & F & General Manager \\
Parent 10 & College Parent & F & CPA Accountant \\
Student 1 & College Student & F & Test Preparation for GRE \\
Student 2 & Public College Student & M & Test Preparation for GRE \& TOEFL \\
Student 3 & High School Student & F & Test Preparation for TOEFL \\
Student 4 & High School Student & F & Test Preparation for TOEFL \\
Student 5 & Private High School Student & F & Test Preparation for TOEFL \\
Student 6 & Private High School Student & M & Test Preparation for SAT \\
Student 7 & Middle School Student & M & Cambridge English Test Preparation \\
Student 8 & Private Middle School Student & M & Test Preparation for TOEFL \\
Student 9 & Private High School Student & M & Test Preparation for IELTS \\
Student 10 & Private High School Student & M & Test Preparation for IELTS \\
\hline
\end{tabular}

Table 2 above shows that there are many students to prepare for the standardized tests because the YBR school is to provide the intensive language training for those students who are preparation for their standardized tests such as TOEFL, IELTS, GRE, Cambridge and other standards course, even some of the students who need to prepare for the national college examination test. Therefore, school principals need to hire the qualified teachers to teach the students intensively. Only if the school could help the students to pass the exam with a high score, the school could be welcomed by the students, and parents. Therefore, the private YBR school face many challenges on how they could offer a qualified teaching and also makes the students and parents who are satisfied with their learning outcomes. 


\section{Data Collection Procedures}

This study collected data through semi-structural interviews and open-ended informal conversations across respondents with an average of 30 minutes. It included the authors' observation, field notes, memos, documents, and transcriptions from his working reflection journal from 2012 to 2019. The author collected teachers' and parents' data in the summer camps in 2015 and 2016 through three to five questions to each of them. The five questions for teachers are: 1). what are your views about the trust between school stakeholders? 2). How would you motivate your students to improve learning outcomes? 3). How would you create a learning community? 4). How do you make a trusting relationship with stakeholders? 5). would you share anything with me? The questions for parents are 1). what is your expectation from school? 2). How do you select a school for your kids? 3). what are the essential factors that are important for you? 4). what is your view about trust among school stakeholders? 5). anything you want to share with me? The author interviewed students informally through phone calls or WeChat to ask their views. The average conversation between author and student is about 30 minutes. The author called the students who studied in the YBR school in 2012 and 2013. The general questions for student interviews are 1). what are the essential values such as trust that you have learned in YBR school? 2). what is your view about trust? 3). how does the school principal help you? 4). what is your good memory in school? 5). anything you want to share with me? Therefore, the data were collected from the year 2012 to 2019 with the author journals.

\section{Data Analysis}

The first and second cycle coding methods were employed to analyze the interview transcripts, field notes, and observation materials in this study (Saldana, 2015). After uploading the transcripts and fields note into the computerized-aided qualitative analysis software, N-Vivo 12, to code, analyze, categorize, and synthesize the major themes (Creswell, 2007; Denzin \& Lincoln, 2005). Specifically, in the first cycle, the author read and re-read the transcripts line by line to identify the categories and subcategories. Then, the author compares the categories that were coded. During the coding, connections were made using the iterative process that involved multiple readings in gaining a more in-depth interpretation of the meaning of the data. The second cycle was done by forming clusters and linking themes to develop the major themes under each of the research questions. The analytic memos on the way of the analysis process were used to document and reflect and capture emergent patterns, concepts, and themes (Saldana, 2015). Finally, the credibility of the data was verified by a member check (Marshall and Rossman, 2015).

\section{Trustworthiness}

The author used the transcripts and field notes to code the data with a coding process to enhance trustworthiness and credibility. He ensured reliability, dependability, confirmability, transferability, and authenticity in this study. The author used the memo to develop themes and created a research audit trail to ensure its quality. The author also invited one of the $\mathrm{Ph} . \mathrm{D}$. candidates to ensure the data is clear enough and accurate and all materials audited (Creswell, 2007; Crotty, 1998). Therefore, the researchers followed the qualitative research disciplines to ensure consistency and trustworthiness in this study.

\section{RESULTS}

All merged and coded data were into the themes that reflect how the school principal in YBR school could work with their students, parents, and teachers to lead the school improvement. The descriptive and interpretative analysis presented how the school principals could generate the core value of building a trust learning environment for student learning outcomes. Therefore, findings related to building trust among stakeholders present per research questions in order. Since some responses were typical, the author provides the quotes to support the main themes found in this study. 


\section{Research Question 1: What Are the Principal's Challenges and Trust Crisis Among Students, Teachers, and Parents in YBR School?}

This study discovered three significant challenges for the YBR school regarding the first research question, which causes schools to trigger a trust crisis. The challenges are the two-side sword, which may lead to a trust crisis and allow the school to establish a trust-centered leadership. Sometimes, school principals trust teachers' teaching and parents' support to help them achieve their learning target as expected; however, the school principals may not receive the same expectations as they hope. Since parents and students have many choices to select the private schools anytime, they might hold the idea of just trying it in this center first and then move to others if the center could not reach their expectations. This situation may cause unstable learning and cause difficulty for the school to monitor and implement the learning process. No matter how the school's difficulty, this study found out that creating a trust-based learning environment is necessary for both school and students to be satisfied in teaching and learning.

The first challenge is that the school stakeholders believe the student testing score result is the priority than any other factors such as trust. Since intensive language training in a private school helps students pass their exams as the student's and parents' expectations, the school always monitors the students' daily learning performance. If the private school could help the students increase their standardized testing scores, the parents and students would continuously learn in the private school and promote the school to their social network if passing the exam with a good score. That is why the school stakeholders pay more attention to the testing score than any others. However, trusting is essential for students, parents, teachers, and school principals to achieve their expectations efficiently.

The second challenge is that the school stakeholders, especially the school principal, may save costs but neglect the students, parents, and teachers' promises and their expectations. Since the private school is commercial-oriented, the school principals need to save the cost and increase school profit. Since the highly qualified teachers in the fields require a high cost, the school might not have the ability to pay the high cost because of the students' lower tuition. This situation might cause the school to lack the resources to hire top teachers. However, the school needs to always respond to the promise and expectation, which is a key for school improvement no matter how difficult it is.

The third challenge is that the school principals may be afraid of losing students because the private school sector is competitive in Beijing. The private school could survive and maintain sustainability by increasing the enrollment rate in Beijing's competitive school sectors. If the school lose the students, they might lose more students because Chinese people rely on guanxi social network and vice versa. Thus, this study emerged three significant themes with quotes selected to prove how school principals face the private school market's challenges, as shown in Table 3 below.

\section{TABLE 3 \\ THREE MAJOR THEMES CHALLENGES WITH QUOTES SELECTED FROM THE PARTICIPANTS}

\begin{tabular}{|c|c|}
\hline Major Themes & Quotes Selected from Participants \\
\hline $\begin{array}{l}\text { Theme 1: Testing Score } \\
\text { Results First, but Trust } \\
\text { Second }\end{array}$ & $\begin{array}{l}\text { - I think my first responsibility is to work with teachers to help the } \\
\text { students to pass their exam. That is my first concern (Principal 1). } \\
\text { - Showing good testing scores helps me to have a good communication } \\
\text { with parents. So, I think it is important. Surely, think beside the score, } \\
\text { I also promote the educational core values such as trust, resilience etc. } \\
\text { (Principal 1). } \\
\text { - When my students tell me that they pass the exam with high score, I } \\
\text { am so proud of it (Teacher 3). } \\
\text { - I pay the high tuition to the school. I think only my kid can pass the } \\
\text { exam with good score. I think it is valuable and acceptable for me } \\
\text { (Parent 1). }\end{array}$ \\
\hline
\end{tabular}


- My goal is to pass the exam through my hard working and learning in the center (Student 6).

Theme 2: Saving Costs but Neglecting the Importance of Promise and Expectation

Theme 3: Worrying about Student Dropout Rate
- Sometimes, I feel I have difficulty to look for the high qualified teachers because the cost is limited, and I cannot offer too much cost to the teacher. It is because the tuition is lower than some of the other students (Principal 1)

- I really feel trouble to make a decision to select the best language center. It is because I am not sure which center could really help my kids to pass the exam and also to receive a holistic guidance (Parent 7)

- Sometimes I feel I am stupid because I select the school for my kids (Parent 4)

- I feel some of my teachers are not qualified, so I dropout and move to other centers to see how it is (Student 10).

- My wage is lower than others although I am over-qualified. Therefore, I am sorry to say some bad things (Teacher 10).

- I know some of the part-time teachers might not pay fully attention to the students in needs and support their learning with a full heart (Principal 1).

- If my kids try several hours or at most 20 hours, my kids feel that they have no satisfaction. I will ask my kids to dropout and also seek other centers for continuously learning (Parent 6)

- I feel not good, I will change and learn from others (Student 9).

Table 3 above shows that school principals create trust among school stakeholders and figure out how to help students to pass the exam, which is the priority. Some students and parents might say that they would drop out of the schools if they could not help them reach their goals with satisfaction and progress. However, this study discovered that creating trust-based learning and teaching is necessary because trust among the stakeholders could help the students save time and achieve their goals effectively. With a trust learning environment, teachers feel valuable, and students feel comfortable. That calls for school principals to gain trust and self-confidence through providing a high quality of educational service (Neve, Devos, \& Tuytens, 2014). Trusting is the best way to work with all school stakeholders to feel satisfied with a positive light (Burke, Sims, Lazzara, \& Salas, 2007). Therefore, trust can lead the school to create a collaborative learning culture and engage the school stakeholders' expectations for school sustainability and development (Louis \& Murphy, 2017; Louis, 2006).

\section{Research Question 2: How Could the Principal Establish and Maintain a Relationship of Trust Among Students, Teachers, and Parents in YBR School?}

Findings show regarding the second research question that school principals could lead the school improvement and establish and maintain a trust-based interpersonal relationship among school stakeholders only if the school could make all of them satisfied. School principals may build a trust relationship with the students only if they could help them pass the exam with a good score and satisfied with the parents' expectations. Private school's characteristics are to effectively guide the students through intensive training to pass the standardized tests with a good score. Only if the private school could train students to pass the exam could increase its high quality of teaching to be recognized by students and parents. The passing score is the decisive measurement for the private school to raise its social image and school improvement.

The school could also offer a high wage to the teachers and create a supportive learning community that makes the teachers feel comfortable. No matter how much private schools need to pay the cost for hiring qualified teachers, the private school needs to respond to the parents, students, and teachers' expectations in leading school improvement. In China's guanxi society, schools always do what they 
promise to sustain their growth in China's competitive school sectors. These strategies, in reality, would possibly create a trust-based learning environment in the YBR school. However, education is not just for creating a high testing score but for also transforming educational core values such as trust and critical ability to the students for their lifelong learning. Therefore, the three major themes with quotes selected were discovered, shown in the table below.

\section{TABLE 4 \\ THREE MAJOR THEME OF ESTABLISHING AND MAINTAINING TRUST WITH QUOTES SELECTED FROM THE PARTICIPANTS}

\begin{tabular}{lcl}
\hline Major Themes & Quotes Selected from Participants \\
\hline Theme 1: Passing Exam & - I can trust school principal only if I pass the exam with a good \\
with Good Testing Score & progress, I think (Student 1). \\
& - I do not want to spend too much money to get nothing (Student 3) \\
& - I want my kids to value to be learned in the school based on the \\
Theme 2: Parents' & I expect school principal can tell me what my kids' learning \\
Expectation with & progress is and how I can help my kids (Parent 2). \\
Communication & I think I can exchange what I observed from the students to their \\
& parent to work together for student learning outcomes (Principal 1) \\
& I want to know why my kids cannot pass the exam with a good \\
& score. I have never received information. I do not know why and \\
& how I can do (Parent 3). \\
Theme 3: Teachers' & I want to get higher wage as possible. Only higher wage can show \\
Engagement with a High & my standards, I think (Teacher 4). \\
Wage and Support & Sometimes I really do not pay too much attention to the wages, but \\
& I really feel I need to work in the good environments and real show \\
& educational core values (Teacher 9). \\
\hline
\end{tabular}

Table 4 shows that school principals can build and maintain a trust relationship with stakeholders because all the stakeholders want to achieve the same goal for student learning outcomes. School principals might face many challenges while making a change in school. Still, they need to create a high-trust learning environment to foster trust among students, teachers, and parents for commitment to the school and themselves in education (Tschannen-Moran, 2009) and manage the school effectively (Wahlstrom \& Louis, 2008). Therefore, school principals create a trust-based learning environment that could form respect, cooperation, self-discipline, and a shared vision for all school improvement (Brinia, Zimianiti, \& Panagiotopoulos, 2014; Liu, Hallinger, \& Feng, 2016).

\section{Research Question 3: How Does the School Principal Promote Trust-Based Leadership to Improve Student Enrollment Rate, Market Share, School Reputation, and Develop Students' Critical, Independent Thinking Ability in YBR School?}

The finding shows that schools could increase enrollment rate, school effectiveness, market share, and school social reputation through several strategies. The first strategy takes advantage of promoting word of mouth. Suppose the school could help the students pass their exams with a high score. In that case, they could directly or indirectly share their learning experiences with the peers, thus allowing the school to increase its enrollment rate and social reputation. Suppose the school could build good communication with parents. In this scenario, the parents could help the school because China's social and cultural norms rely on Guanxi (interpersonal) to enlarge the social network for their professional service. The second strategy is that the school principals could offer a high quality of educational support to all the students with a heart, responsibility, and full professional help for students' success. Thus, by embracing educational providers' 
high quality, the school could build its social reputation and receive school stakeholders' support for school improvement and increase its market share. Finally, the school should promote its educational vision and mission with successful examples to make all the promotions reliable and welcomed by the students, parents, and society. Therefore, the three major themes discovered in the study were shown in table 5 below.

\section{TABLE 5 \\ THREE MAJOR THEMES OF STRATEGIES FOR SCHOOL IMPROVEMENT WITH QUOTES SELECTED FROM THE PARTICIPANTS}

\begin{tabular}{|c|c|}
\hline Major Themes & Quotes Selected from Participants \\
\hline Theme 1: Word of Mouth & $\begin{array}{l}\text { - I believe the word of mouth is the best way for school promotion, } \\
\text { I think (Principal 1). } \\
\text { - I surely promote the school I teach because I feel valuable and it } \\
\text { is good school (Teacher 10). } \\
\text { - I want to say my school is good enough to my classmates (Student } \\
\text { 2). } \\
\text { - I shared my kid's success with my friends freely (Parent 2). }\end{array}$ \\
\hline Theme 2: Best Service & $\begin{array}{l}\text { - I think providing education with a heart and full responsibility can } \\
\text { help me to freely talk with students, parents, and teachers } \\
\text { (Principal 1). } \\
\text { - I like to work with the school which pay all the attention to the } \\
\text { students' needs (Teacher } 8 \text { ). }\end{array}$ \\
\hline Theme 3: Market Promotion & $\begin{array}{l}\text { - I think promotion is needed, but still need to focus on the current } \\
\text { student service (Principal 1). } \\
\text { - When I share my good experiences with peers, I feel proud. So, I } \\
\text { will say some to them, I think (Student 2). }\end{array}$ \\
\hline
\end{tabular}

Table 5 indicated that school principals need to pay attention to word-of-mouth strategies for school enrollment rate, school effectiveness, and school social reputations. Most of the participants showed that they indeed shared their good experiences from the school with others, which could help the school to improve its social image. Thus, the school principals generate a trust-based learning environment that can provide high quality with respect, loyalty, and school exploration commitment for school improvement (Groote \& Berschi-Michel, 2020; Louis \& Murphy, 2017; Tan, Gao, \& Shi, 2020; Thornton, 2021).

\section{CONCLUSION, IMPLICATION, AND RECOMMENDATION}

\section{Conclusion}

This study concluded that school principal in YBR school needs to promote trust-based leadership for school stakeholders' commitment, school effectiveness, and student outcomes. The study also found that the school faces three significant challenges: testing score first, but trust second; saving costs, but neglecting the importance of promise and expectation; and worrying student dropout. Additionally, the YBR school can maintain and establish a trust-learning environment by helping students pass the exam with good teaching, communicating with parents and teachers, and increasing their wages if high-qualified (Tan \& Chee, 2005). Finally, the school principals could improve the school enrollment rate, social reputation, and student achievement through the strategies: word of mouth, best-service, and market promotion (Crane, 2020).

\section{Implication and Recommendation}

This study explores the school principal, teacher, student, and parents' experiences and perceptions in the private language training centers in Beijing to fill up the private minban school literature gap in 
education in China. Therefore, the study suggests that the school principals, together with all school stakeholders, build trust-based learning and teaching environment is necessary for school effectiveness in the high-power distance school context in China (Cruz, Marchanda, Firestone, \& Rodl, 2020; Davies, Edney, \& Wang, 2020; Mauk, 2019; Tsai et al., 2020; Weinstein, Raczynski, \& Pena, 2020). This study also found out that testing score is the priority for the language training centers, but still need to offer a core value holistic training, such as trust, loyalty, resilience, and empathy in teaching and learning among school stakeholders (Scott, 1980).

The increasing multicultural-racial school contexts in the United States and the number of migrated students in China, the gap between rich and poor, between urban and suburban, may appear to be injustice, inequality, and biases among the stakeholders. Khalifa, Gooden, and Davis (2016) pointed out that school needs to promote antiracism, which could support leaders' personal growth and unearths their personal biases and values, such as trust that stem from their cultural background. School principals also need to promote social justice in the multicultural school background (Branch, Hanshek, \& Rivkin, 2013). Also, the dual language program has been increasing both in the United States and China; however, school principals may need to improve their leadership capacity to effectively lead the dual program improvement (Ringler \& Jones, 2020). Therefore, the future study suggests exploring the experiences of school principals, teachers, students, and parents on how they understand the school principals' role, such as antiracist leaders between the United States and China, in leading school effectiveness in the dual-language program.

\section{REFERENCES}

Alazmi, A.A., \& Ai-Mahdy, Y.F.H. (2020). Principal authentic leadership and teacher engagement in Kuwait's educational reform context. Educational Management Administration \& Leadership, pp. $1-21$.

Baik, D., Russell, D., Jordan, L., Matlock, D.D., Dooley, F., \& Creber, R.M. (2020). Building trust and facilitating care conversations: A qualitative study in people with heart failure receiving home hospice care. Palliative Medicine, 34(7), 925-933.

Baktir, Z., \& Watson, F. (2020). Trust-driven entrepreneurship for community well-being of refugees and their local hosts. Journal of Macromarketing, pp. 1-16.

Branch, G.F., Hanushek, E.A., \& Rivkin, S.G. (2013). School leaders matter. Education Next, pp. 62-69.

Brinia, V., Zimianiti, L., \& Panagiotopoulos, K. (2014). The role of the principal's emotional intelligence in primary education leadership. Educational Management Administration \& Leadership, 42(4S), $28-44$.

Bryk, A.S., \& Schneider, B. (2002). Trust in schools: A core resource for improvement. New York: Russell Sage.

Burke, C.S., Sims, D.E., Lazzara, E.H., \& Salas, E. (2007). Trust in leadership: A multi-level review and integration. The Leadership Quarterly, 18, 606-632.

Coban, O., Ozdemir, N., \& Bellibas, M.S. (2020). Trust in principals, leaders' focus on instruction, teacher collaboration, and teacher self-efficacy: Testing a multilevel mediation model. Educational Management Administration \& Leadership, pp. 1-21.

Cosner, S. (2009). Building organizational capacity through trust. Educational Administration Quarterly, 45(2), 248-291.

Crane, B. (2020). Revisiting who, when, and why stakeholders matter: Trust and stakeholder connectedness. Business \& Society, 59(2), 263-286.

Creswell. (2007). Qualitative inquiry and research design: Choosing among five approaches. Los Angeles, CA: Sage.

Crotty, M. (1998). The foundations of social research. Los Angeles, CA: Sage.

Cruz, R.A., Manchanda, S., Firestone, A.R., \& Rodl, J. (2020). An examination of teachers' culturally responsive teaching self-efficacy. Teacher Education and Special Education, 43(3), 197-214.

Davies, G.A., Edney, K., \& Wang, B. (2020). National images, trust, and international friendship: Evidence from Chinese students. International Relations, pp. 1-21. 
De Groote, J.K., \& Bertschi-Michel, A. (2020). From intention to trust to behavioral trust: Trust-building in family business advising. Family Business Review, pp. 1-22.

Denzin, N.K., \& Lincoln, Y.S. (1994). The Sage handbook of qualitative research (3rd ed.). Thousand Oaks: Sage.

Ding, W. (2004, March 26). Zhou Ji: No choice students for public schools; parental choice for minban schools; reputable schools run minban schools. People's Daily, 11 [in Chinese].

Dong, H., \& Li, L. (2019). School choice in China: Past, present, and future. ECNU Review of Education, 2(1), 95-103.

Erden, A., \& Erden, H. (2009). Predicting organizational trust level of school managers and teachers at elementary schools. Procedia Social and Behavioral Sciences, 1, 2180-2190.

Festenstein, M. (2020). Political trust, commitment, and responsiveness. Political Studies, 68(2), 446462.

Ghamrawi, N. (2011). Trust me: Your school can be better-A message from teachers to principals. Educational Management Administration \& Leadership, 39(3), 333-348.

Gregory, A., Hafen, C.A., Ruzek, E., Mikami, A.Y., Allen, J.P., \& Pianta, R.C. (2016). Closing the racial discipline gap in classrooms by changing teacher practice. School Psychology Review, 45(2), 171-191.

Handford, V., \& Leithwood, K. (2013). Why teachers trust school leaders. Journal of Educational Administration, 51, 194-212.

Huang, Z., Wang, T., \& Li, X. (2016). The political dynamics of educational changes in China. Policy Futures in Education, 14(1), 24-41.

Janvier, A., Farlow, B., Barrington, K.J., Bourque, C.J., Brazg, T., \& Wilfond, B. (2020). Building trust and improving communication with parents of children with Trisomy 13 and 18: A mixedmethods study. Palliative Medicine, 34(3), 262-271.

Johnston, J.M., \& Shipway, B. (2020). Readiness to lead: A tentative tool for analysis. International Journal of Educational Management, 34(8).

Khalifa, M.A., Gooden, M.A., \& Davis, J.E. (2016). Culturally responsive school leadership: A synthesis of the literature. Review of Educational Research, 86(4), 1272-1311.

Kwak, J., Tomescu-Dubrow, I., Slomczynski, K.M., \& Dubrow, J.K. (2020). Youth, institutional trust, and democratic backsliding. American Behavioral Scientist, 64(9), 1366-1390.

Li, L., Hallinger, P., \& Walker, A. (2016). Exploring the mediating effects of trust on principal leadership and teacher professional learning in Hong Kong primary school. Educational Management Administration \& Leadership, 44(1), 20-42.

Lin, X., \& Huang, H. (2017). From strong guanxi to weak guanxi: Connectivity in Chinese micro-charity. Chinese Journal of Sociology, 3(3), 473-487.

Lincoln, Y.M., \& Guba, E. (1985). Naturalistic inquiry. New York: Sage.

Liu, S., \& Apple, M.W. (2016). Parental choice of school, class strategies, and educational inequality: An essay review of school choice in China-A different tale? Educational Policy, 30(6), 940-955.

Liu, S., \& Hallinger, P. (2018). Principal instructional leadership, teacher self-efficacy, and teacher professional learning in China: Testing a mediated-effects model. Educational Administration Quarterly, 54(4), 501-528.

Liu, S., Hallinger, P., \& Feng, D. (2016). Learning-centered leadership and teacher learning in China: Does trust matter? Journal of Educational Administration, 54, 661-682.

Louis, K.S. (2006). Changing the culture of schools: Professional community, organizational learning, and trust. Journal of School Leadership, 16, 477-489.

Louis, K.S., \& Murphy, J. (2017). Trust, caring and organizational learning: The leader's role. Journal of Educational Administration, 55(1), 103-126.

Lyu, M., Li, W., \& Xie, Y. (2019). The influences of family background and structural factors on children's academic performances: A cross-country comparative study. Chinese Journal of Sociology, 5(2), 173-192.

Marshall, C., \& Rossman, G.B. (2015). Designing Qualitative Research (6th ed). London: Sage Publication.

76 Journal of Higher Education Theory and Practice Vol. 21(6) 2021 
Mauk, M. (2019). Disentangling an elusive relationship: How democratic value orientations affect political trust in different regimes. Political Research Quarterly. Retrieved from https://journals.sagepub.com/doi/abs/10.1177/1065912919829832

Ministry of Education of the People's Republic of China. (2019). The Communist Party of China Central Committee and the State Council recently issued China's education modernization 2035.

Retrieved from http://www.moe.gov.cn/jyb_xwfb/s6052/moe_838/201902/t20190223_370857.htm [in Chinese]

Neve, D.D., Devos, G., \& Tuytens, M. (2014). The importance of job resources and self-efficacy for beginning teachers' professional learning in differentiated instruction. Teaching and Teacher Education, 47, 30-41.

Rincon-Gallardo, S., \& Fullan, M. (2016). Essential features of effective networks in education. Journal of Professional Capital and Community, 1(1), 5-22.

Ringler, M., \& Jones, K. (2020). Preparing school leaders for dual language programs in rural settings. Handbook of Research on Leadership and Advocacy for Children and Families in Rural Poverty, pp. 344-358.

Saldana, J. (2015). The coding manual for qualitative researchers (3rd ed). London: Sage Publication.

Scott, C.L., III. (1980). Interpersonal trust: a comparison of attitudinal and situational factors. Human Relations, 33, 805-812.

Skaalvik, E.M., \& Skaalvik, S. (2011). Teacher job satisfaction and motivation to leave the teaching profession: Relations with school context, feeling of belongs, and emotional exhaustion. Teaching and Teacher Education, 27, 1029-1038.

Tan, C.Y., Gao, L., \& Shi, M. (2020). Second-order meta-analysis synthesizing the evidence on associations between school leadership and different school outcomes. Educational Management Administration \& Leadership, pp. 1-22.

Tan, H.H., \& Chee, D. (2005). Understanding interpersonal trust in a Confucian-influenced society. International Journal of Cross-Cultural Management, 5(2), 197-212.

Thornton, K. (2021). Leading through COVID-19: New Zealand secondary principals describe their reality. Educational Management Administration \& Leadership, pp. 1-17.

Tsai, L.L., Morse, B.S., \& Blair, R.A. (2020). Building credibility and cooperation in low-trust settings: Persuasion and source accountability in Liberia during the 2014-2015 Ebola crisis. Comparative Political Studies, 53(10-11), 1582-1618.

Tschannen-Moran, M. (2004). Trust matters: Leadership for successful schools. San Francisco, CA: Jossey-Bass.

Tschannen-Moran, M. (2009). Fostering teacher professionalism in schools: The role of leadership orientation and trust. Educational Administration Quarterly, 45(2), 217-247.

Van Maele, D., \& Van Houtte, M. (2012). The role of teacher and faculty trust in forming teachers' job satisfaction: Do years of experience make a difference? Teaching and Teacher Education, 28, 879-889.

Wahlstrom, K.L., \& Louis, K.S. (2008). How teachers experience principal leadership: The roles of professional community, trust, efficacy, and shared responsibility. Educational Administration Quarterly, 44(4), 458-495.

Weinstein, J., Raczynski, D., \& Pena, J. (2020). Relational trust and positional power between school principals and teachers in Chile: A study of primary schools. Educational Management Administration \& Leadership, 48(1), 64-81.

Yan, S., \& Yang, Y. (2020). Education informatization 2.0 in China: Motivation, framework, and vision. ECNU Review of Education, pp. 1-19.

Zhang, W., \& Koshmanova, T. (2020). A Comparative Study of School Principal Experiences:

Recontextualization of Best American School Principals of Using Technology in China. In G.H. Marks \& D. Schmidt-Crawford (Eds.), Proceedings of Society for Information Technology \& Teacher Education International Conference (pp. 651-656). Online: Association for the Advancement of Computing in Education (AACE). Retrieved April 21, 2020, from 
https://www.learntechlib.org/primary/p/215808/

Zhang, W., \& Koshmanova, T. (2020). Chinese school principal views on trust, learning-centered leadership and teacher learning in the test-oriented educational environment. ICERi2020Proceedings, pp. 86-92.

Zhang, W., \& Koshmanova, T. (2020). Chinese school teachers view on critical thinking, self-direction, and problem-solving skills on student success in an international high school in Beijing. ICERi2020-Proceedings, pp. 3026-3030.

Zhang, W., \& Koshmanova, T. (2020). Creating A Teacher Collaborative Practice in An International High School in Beijing: The Role of The Principal. Edulearn20 Proceedings, pp. 1760-1768.

Zhang, W., \& Koshmanova, T. (2020). Relationship between factors and graduation rates for student success in the U.S. college. Proceeding of the $9^{\text {th }}$ European Conference on Education. Retrieved from https://ece.iafor.org/publishing-opportunities/

Zhang, W., \& Koshmanova, T. (2020). Transformational school leaders support teachers to foster student grit. Proceedings of the Asian Conference on Arts \& Humanities. Retrieved from $\mathrm{http}: / / 25 \mathrm{qt} 511 \mathrm{nswfi} 49$ iayd31 ch80-wpengine.netdna-ssl.com/wpcontent/uploads/papers/acah2020/ACAH2020_57579.pdf

Zhang, W., \& Koshmanova, T. (2020). Understanding the Impact of Race, Socioeconomic Status on Student Achievement for Secondary School Students. International Journal of Education and Human Developments, 6(3), 5-10.

Zhu, Y. (2019). New national initiatives of modernizing education in China. ECNU Review of Education, 2(3), 353-362. 